\title{
Number of Experiments that Should be Considered in the Cluster Analysis of Common Bean Genotypes for Plant Architecture and Grain Yield Traits
}

Nerinéia Dalfollo Ribeiro ( $\square$ nerineia@hotmail.com )

Universidade Federal de Santa Maria https://orcid.org/0000-0002-5539-0160

Sandra Maria Maziero

Universidade Federal da Fronteira Sul

\section{Research Article}

Keywords: Phaseolus vulgaris L., Genotype × experiment interaction, Mahalanobis' generalized distance, Tocher's cluster analysis, UPGMA cluster analysis.

Posted Date: November 10th, 2021

DOI: https://doi.org/10.21203/rs.3.rs-979940/v1

License: (c) (1) This work is licensed under a Creative Commons Attribution 4.0 International License. Read Full License 


\section{Abstract}

The number of experiments that allows the choice of parents to be used in controlled crossings in a more assertive way in cluster analysis is unknown for plant architecture and grain yield traits in common bean. Therefore, the objective of this work was to determine the number of experiments that should be considered in Tocher's and the unweighted pair group method with arithmetic mean (UPGMA) cluster analyses to identify promising common bean parents for several plant architecture and grain yield traits. Four experiments were carried out in different years and growing seasons, in the same site. The randomized block design was used and 17 common bean genotypes with carioca (beige seed coat with brown streaks) and black grains were evaluated in relation to 12 traits related to plant architecture and five traits related to grain yield. Statistical analyses were performed with data obtained from individual and combined experiments. Significant genotype $\times$ experiment interaction was observed for most of the evaluated traits. When Tocher's and UPGMA cluster analyses was performed from data obtained in individual experiments different groups were formed. The use from data obtained in two, three ou four experiments allowed greather reliability in the formation of groups. Three and two experiments are sufficient in the Tocher's and the UPGMA cluster analyses, respectively, to identify promising carioca and black common bean parents for several plant architecture and grain yield traits in a more assertive way.

\section{Introduction}

The breeding of beans (Phaseolus vulgaris L.) in Brazil began with the creation of the Agronomic Station of Campinas in 1887, which years later received the name Agronomic Institute of Campinas (Carbonell et al. 2012). Since then, the development of high-yielding common bean cultivars has been one of the main objectives of breeding programs. In the last decades, more efforts have been concentrated on the selection for upright plant architecture, which allows the harvest to be carried out manually or with a harvester, to obtain less grain loss. The plant architecture in common bean has been evaluated by lodging, insertion of the first pod, plant height and other traits described by Moura et al. (2013), Soltani et al. (2016) and Nadeem et al. (2020).

To increase the chances of success in the development of new common bean cultivars with high grain yield and upright plant architecture, it is necessary to know the genetic divergence of the superior parents to be used in controlled crossings. Cluster analyses, especially Tocher and UPGMA, have been shown to be efficient for the identification of superior common bean parents for agronomic (Gonçalves et al. 2016; dos Santos et al. 2019) and for seed morphological (Gonçalves et al. 2014) traits. However, most of the researches carried out to date consider data obtained in a single experiment for studies of genetic divergence of common bean genotypes based on agronomic traits (Correa and Gonçalves 2012; de Lima et al. 2012; Bertoldo et al. 2014; Gonçalves et al. 2016; dos Santos et al. 2019). Therefore, these works not consider the effects of genotype $x$ experiment (environment) interaction that have been reported for most agronomic traits evaluated in common bean genotypes (Moura et al. 2013; Boros et al. 2014; Soltani et al. 2016; Delfini et al. 2017; Nadeem et al. 2020) in the choice of parents to be used in the crossbreeding blocks.

When significant genotype $\times$ experiment interaction is observed for agronomic traits in common bean, it is necessary to consider the environmental variability between years and growing seasons for the same site of conduction of the experiments in the cluster analysis. For this reason, Cargnelutti Filho et al. (2009) recommended that data obtained in six and seven experiments are sufficient to identify divergent common bean cultivars for grain yield, phenological and morphological traits in Tocher's and Ward cluster analyses, respectively. However, these authors evaluated few traits related by plant architecture. Additionally, the use of data obtained in six or seven experiments to identify superior parents based in several plant architecture and grain yield traits to be used in a breeding program is not viable, as this would involve a lot of analysis time, making this step extremely expensive and laborious.

The number of experiments that allows the identification of promising common bean parents for several plant architecture and grain yield traits in a more assertive way in cluster analysis should allow greater efficiency, accuracy and speed in the selection of genotypes that will be used for controlled crosses. This information is not known and constitutes an important innovation for common-bean breeding programs. Therefore, the objective of this work was to determine the number of experiments that should be considered in the Tocher's and the UPGMA cluster analyses to identify promising common bean parents for several plant architecture and grain yield traits.

\section{Materials And Methods Conducting experiments}

Four experiments were carried out in the area of the Common-Bean Breeding Program of the Federal University of Santa Maria (UFSM), Santa Maria, Rio

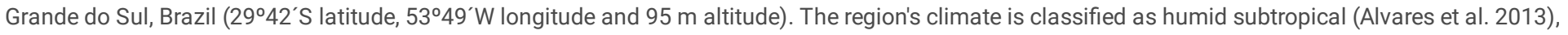
which allows the cultivation of common bean in rainy and dry season crops. The sowing of the rainy season experiments (2016 and 2017 ) was performed in October and dry season experiments (2017 and 2018), in February. The experimental area was maintained with green cover between July and September with the cultivation of black oats.

The randomized block design was used with three replicates. The experimental plot was formed of 4-m four long rows, with spacing between lines of $0.5 \mathrm{~m}$, but only the two central lines were considered as useful area $\left(4 \mathrm{~m}^{2}\right)$. The treatments consisted of 17 common bean genotypes, being four cultivars (Pérola, Carioca, BRS Valente and Guapo Brilhante) and 13 lines obtained by different research institutions that participated of the Value of Cultivation andUse (VCU) experiment of Common-Bean Southern-Brazilian network in the 2016 and 2017 biennial (SM 0312, BRS MG Uai, CNFC 15 097, LEC 02-16, GEN 45-2F293P, LP 09-33, LEC 01-16, IAC Netuno, LP 11-117, TB 02-19, CHP 04-239-52, CHP 01-182-48 and TB 03-11). These genotypes have carioca (beige seed coat with brown streaks) and black beans, both from the Mesoamerican gene pool, being representative of the most produced grain types in Brazil. 
The soil of the experimental area is classified as typic alitic Argisol, Hapludalf, and was prepared with plowing and harrowing, which corresponds to conventional cultivation. Fertilization, control of weed and insects, and irrigation were performed in accordance with technical recommendations for the cultivation of common bean in the Southern region of Brazil (Ctsbf 2012). Disease control was not carried out in compliance with the rules established for conducting common bean VCU experiments in Brazil (Brasil 2006).

\section{Traits related to plant architecture and grain yield}

The plant architecture was evaluated at maturation stage (R9) by 12 traits. The two qualitative traits, lodging and general adaptation score, were determined in the useful area of the plots using score scales ranging from 1 to 9 . For lodging, score 1 characterized upright plants and score 9 was assigned to prostrate plants. For general adaptation score, score 1 defined upright plants, with a large number of pods per plant and without symptoms of disease in the pods and score 9 represented prostrate plants, with few pods per plant and high severity of disease symptoms in the pods.

The other evaluations of the plant architecture included quantitative traits that were analyzed in 10 plant representatives of the useful area and harvested at random. The following traits were measured with a measuring tape and showed in $\mathrm{cm}$ : insertion of the first pod, insertion of the last pod, plant height, firstinternode length, second-internode length, third-internode length, fourth-internode length and fifth-internode length. The hypocotyl and epicotyl diameters were measured with a digital caliper, in $\mathrm{mm}, 1 \mathrm{~cm}$ below and $1 \mathrm{~cm}$ above the cotyledon node, respectively.

The five traits related to grain yield determined were number of pods per plant, number of grains per plant, number of grains per pod, mass of 100 grains and grain yield. These traits were evaluated in the 10 plants collected at random in the useful area, except for the grain yield that was calculated from the data obtained in all plants harvested in the useful area. Grain moisture was standardized at $13 \%$ to obtain the mass of $100 \mathrm{grains}(\mathrm{g})$ and grain yield $(\mathrm{kg}$ ha 1).

\section{Statistical analyses}

The data obtained were subjected to individual analysis of variance considering the following experiments: 2016 rainy (I), 2017 dry (II), 2017 rainy (III) and 2018 dry (IV) season crops. Hartley's maximum F-test was applied to verify the homogeneity of the residual variances.

The combined analyses of variance were performed considering the data obtained in the experiments I and II (2016 rainy and 2017 dry season crops), I, II and III (2016 rainy, 2017 dry and 2017 rainy season crops) and I, II, III and IV (2016 rainy, 2017 dry, 2017 rainy and 2018 dry season crops). In the these analyses, genotype effect was analyzed as fixed and the other effects (experiment, genotype $\times$ experiment interaction and error) were random. Since the ratio between the highest and lowest residue mean square was greater than seven, it was necessary to correct the degrees of freedom of the error and of the genotype $\times$ experiment interaction (Cruz 2016) and this allowed homogeneous residual variances to be obtained for all evaluated traits.

Multicollinearity diagnostics was made with the phenotypic correlation matrix obtained in the combined analysis of variance of the four experiments (I, II, III and IV). The condition number (CN), which corresponds to the relationship between the highest and lowest eigenvalue of the matrix, was evaluated according to the collinearity classes established by Montgomery et al. (2012). The exclusion of highly correlated traits and with greater weight in the last eigenvectors was performed to obtain weak collinearity, that is, $\mathrm{CN} \leq 100$, before performing the cluster analyses.

The cluster analyses considered the data obtained for invidual (I, II, III and IV) and combined (I and II; I, II and III; and I, II, III and IV) experiments. For this, the residual variance and covariance matrices obtained in the variance analyses of these experiments were used to generate the genetic dissimilarity matrices between the common bean genotypes using Mahalanobis' generalized distance with standardized means. The Mahalanobis' generalized distance analysis were also applied to identify traits with the greatest contribution to genetic divergence considering indivudual and combined experiments.

The following cluster analyses were performed for individual (I, II, III and IV) and combined (I and II; I, II and III; and I, II, III and IV) experiments: Tocher's optimization and hierarchical unweighted pair group method with arithmetic mean (UPGMA). The cophenetic correlation coefficient (CCC) was established from Pearson's linear correlation between the elements of the cophenetic matrix and the elements of the dissimilarity matrix to verify the consistency of the clustering pattern. All statistical analyses were performed using the Genes program (Cruz 2016).

\section{Results And Discussion Individual and combined analyses of variance}

Significant genotype $\times$ experiment interaction was observed for most of the traits evaluated in one or more combined analysis of variance (Table 1 ). Therefore, the agronomic performance of the common bean genotypes was not constant in the different years and growing seasons. Similarly, significant genotype $\times$ experiment (environment) interaction has been described for most of the plant architecture and grain yield traits evaluated in common bean genotypes (Moura et al. 2013; Boros et al. 2014; Maziero et al. 2015; Soltani et al. 2016; Delfini et al. 2017; Ribeiro et al. 2018; Nadeem et al. 2020). When a significant genotype $\times$ experiment interaction is observed for several agronomic traits in common bean, it is not recommended that cluster analysis be performed based on data obtained in a single experiment, because this strategy does not consider the environmental variability between years and growing seasons for the same site of conduction of the experiments (Cargnelutti Filho et al. 2009). 
There was a significant genotype effect for most of the evaluated traits in individual and combined experiments. Therefore, there is genetic variability for the plant architecture and grain yield traits in common bean genotypes and this allowed the study of genetic divergence. However, no significant genotype $\times$ experiment interaction and genotype effects were observed to the first-internode length, fourth-internode length and fifth-internode length in the experiments combined (I and II; II II and III; and I, II, III and IV). Therefore, these traits were not included in the cluster analyses.

The diagnosis of multicolinearity revealed $\mathrm{CN}=3273.23$, which corresponds to the severe collinearity class according to the criteria proposed by Montgomery et al. (2012). Therefore, it was necessary to exclude the traits with high correlation and with greater weight in the last autovectors: thirdinternode length, number of grains per plant, plant height and epicotyl diameter. The removal of these four traits resulted in weak collinearity ( $\mathrm{CN}=75.26)$ and this prevented multicollinear variables from implicitly receiving greater weights in cluster analyses (Cruz and Carneiro 2006), allowing the correct interpretation of the results obtained in the cluster analyses.

\section{Tocher's cluster analysis}

The results obtained in the Mahalanobis' generalized distance showed that the order of the three traits which showed greater participation for the differentiation of common bean genotypes was different when considering data obtained in individual (I, II, III and IV) experiments (Table 2). However, the mass of 100 grains was the trait that most contributed to the differentiation between common bean genotypes in the combined experiments I and II (29.36\%), I, II and III (29.44\%) and I, II, III and IV (31.51\%). Similarly, it was found that the mass of 100 grains exhibited the greatest relative contribution to the separation of common bean genotypes, although the order of the other agronomic traits important the recognition of these differences varied in each evaluation year, when the Mahalanobis' generalized distance was used (Coelho et al. 2010). The mass of 100 grains, too, has been described as the most important agronomic trait to assess the genetic dissimilarity of common bean genotypes based on data obtained in one (Correa and Gonçalves 2012) or three (Cabral et al. 2011) experiments.

In the present study, the mass of 100 grains has a greater contribution in the formation of different groups in the cluster analyses, using the results obtained in two, three or four experiments. Therefore, data obtained in two experiments were sufficient to recognize differences between carioca and black bean genotypes, based on plant architecture and grain yield traits, in the Mahalanobis' generalized distance analysis.

When Tocher's cluster analysis was performed from data obtained in individual experiments, it was observed that the number of groups formed and the composition of these groups was different (Table 3). This can be explained by the fact that most of the plant architecture and grain yield traits showed a significant genotype $\times$ experiment interaction effect (Table 1). When this happens, the selection of superior parents for agronomic trais will be different in each experiment, and this represents difficulties for the common-bean breeding programs. Previous studies have also shown that the groups formed in the Tocher's cluster analysis were not exactly the same for each of the different environments, since significant genotype $\times$ experiment interaction was found for most of the agronomic traits evaluated by Ceolin et al. (2007) and Coelho et al. (2010). These authors observed that the groups formed in the Tocher's cluster analysis were different for each evaluated experiment (environment). Therefore, when a significant genotype $\times$ experiment interaction is observed for most agronomic traits, the strategy of presenting the results obtained in the Tocher's analysis for each growing environment is not the best option for the breeding program. This is because the identification of superior or redundant genotypes will vary with the growing environment.

Therefore, the environmental variability between growing seasons and years for the same location where the experiments are conducted must be considered in the cluster analysis. Cargnelutti Filho et al. (2009) recommended that data obtained from six experiments were sufficient to identify divergent cultivars by Tocher's cluster analysis based on grain yield, phenology and morphology traits. However, using data obtained from six experiments to identify superior parents or duplicate accessions in a breeding program implies an increase in the time needed to assess genetic divergence and a lot of delay in making decisions regarding the genotypes that can be used in the crossbreeding blocks.

Data from two experiments (I and II) resulted in the division of common bean genotypes into two groups (Table 3), making it possible to differentiate the line TB 02-19 (group 2) from the other evaluated genotypes (group 1). However, when considering the data obtained in three (I, II and III) or four (I, II, III and IV) experiments, it was possible to differentiate three groups with identical composition. Group 1 included 15 carioca and black bean genotypes, corresponding to $88.23 \%$ of the evaluated genotypes; group 2 consisted of the cultivar Pérola (carioca beans); and group 3 was composed of line TB $02-19$ (black beans). Tocher's cluster analysis has been efficient in differentiating common bean genotypes for agronomic traits, despite the fact that group 1 normally concentrates the largest number of evaluated genotypes (de Lima et al. 2012; Gonçalves et al. 2016; Pereira et al. 2019; dos Santos et al. 2019). The use from data obtained in three or four experiments allowed greather reliability in the formation of groups in the Tocher's cluster analysis, in the presesent study.

The data obtained in three or four experiments allowed recognition of the differences between the common bean genotypes grouped in each of the three groups. Group 1 included the common bean genotypes of upright plant architecture, characterized by the lowest lodging and general adaptation score values and the largest hypocotyl diameter (Table 4). These genotypes, also, had the highest number of pods per plant, number of grains per pod and grain yield values, among the three groups formed. Groups 2 and 3 were characterized by common bean genotypes of upright plant architecture, that is, higher second-internode length value; however, they showed low grain yield. All evaluated genotypes had medium-sized grains ( 25 to $40 \mathrm{~g}$ ), which meet the market demand for carioca and black beans (Carbonell et al. 2010). The results obtained showed that the common bean genotypes in group 1 have a greater number of traits that confer an upright plant architecture and high grain yield, with great potential for use in controlled crosses.

In the present study, the groups formed in the Tocher's cluster analysis were identical when considering data obtained in three or four experiments. Therefore, data obtained in three experiments were sufficient for studies of genetic divergence in the Tocher's cluster analysis, allowing the identification of

Page 4/12 
carioca and black common bean parents with a greater number of taits that confer upright plant architecture and high grain yield.

\section{UPGMA cluster analysis}

The lowest CCC was obtained in the UPGMA cluster analysis performed with data obtained in the 2016 rainy (0.5591) and the largest CCC was found with data obtained in the 2017 dry (0.9335) season crops (Figure 1), all of which were significant at $1 \%$ probability by the $t$ test. A similar amplitude of variation was observed for CCC values obtained in the UPGMA cluster analysis, considering agronomic and/or morphological traits evaluated in one (Gonçalves et al. 2014, 2016), two (Arteaga et al. 2019) and three (Cabral et al. 2011) experiments with different common bean genotypes. The closer to one the CCC value, the greater the adjustment between the cophenetic matrix and the dissimilarity matrix based on the Mahalanobis' generalized distance, resulting in greater cluster reliability (Cabral et al. 2011). In the present study, the highest CCC values ( $\geq 0.8746$ ) were obtained in the 2017 dry season (Figure 1 ) and the combined experiments I and II; I, II and III; and I, II, III and IV (Figure 2), indicating greater reliability in the representation of the groups formed in this UPGMA cluster analysis.

The groups formed in the 2016 rainy, 2017 dry, 2017 rainy and 2018 dry season crops were different in the dendrograms obtained in the UPGMA cluster analysis (Figure 1), confirming the results observed in the Tocher's cluster analysis (Table 3). This is because when cluster analysis was performed based on data obtained in a single experiment, the environmental variability between years and growing seasons for the same site of conduct of the experiments was not considered. In the present study, it was possible to verify that when the UPGMA cluster analysis was performed with data from one experiment, there was no repeatability in the characterizing the genetic divergence of carioca and black bean genotypes for plant architecture and grain yield traits.

However, the dendrograms generated in the UPGMA cluster analysis, considering data from two, three and four experiments, formed two identical groups adopting $70 \%$ similarity as a criterion for defining the groups (Figure 2). Group 1 contained the line TB 02-19 and group II was composed of other carioca and black common bean lines and cultivars. When the UPGMA cluster analysis was applied to morphological traits evaluated in two experiments with common bean genotypes, it was also possible to group the genotypes into just two groups (Guidoti et al. 2018; Arteaga et al. 2019). In the present study, it was not possible to gather in different groups carioca and black common bean genotypes for the plant architecture and grain yield traits. The difficulty of separating carioca and black common bean genotypes into different groups by cluster analysis was also reported for agronomic (Pereira et al. 2019) and molecular (Veloso et al. 2015) traits. As in the process of developing new carioca and black common bean cultivars, crosses between parents with both types of grains were carried out, this resulted in genetic similarity (Veloso et al. 2015). For this reason, carioca and black common bean lines and cultivars have a narrow genetic basis, making it difficult to differentiate common bean genotypes from grain types to agronomic traits (Delfini et al. 2017; Pereira et al. 2019).

The results obtained in the UPGMA cluster analysis showed that the inclusion of data obtained in three or four experiments did not change the clustering pattern of common bean genotypes in relation to the analysis with data from two experiments. Therefore, data from two experiments were sufficient in the UPGMA cluster analysis to obtain a dendrogram with high reliability in the formation of the groups. This allows the identification of promising carioca and black common bean parents for plant architecture and grain yield traits in a more assertive manner.

\section{Conclusions}

Data obtained from three and two experiments are sufficient in the Tocher's and the UPGMA cluster analyses, respectively, to identify promising carioca and black common bean parents for several plant architecture and grain yield traits and in a more assertive manner.

\section{Declarations}

Funding: $\mathrm{CNPq}$

Conflicts of interest: The authors declare that they have no conflict of interest.

Availability of data and material: All data generated or analysed during this study are included in this published article.

Acknowledgements To the National Council for Scientific and Technological Development (CNPq) for financial support and scholarships.

\section{References}

1. Alvares CA, Stape JL, Sentelhas PC, Gonçalves JLM, Sparovek G (2013) Köppen's climate classification map for Brazil. Meteorol Z 22:711-728. https://doi.org/10.1127/0941-2948/2013/0507

2. Arteaga S, Yabor L, Torres J, Solbes E, Muñoz E, Diéz MJ, Vicente O, Boscaiu M (2019) Morphological and agronomic characterization of Spanish landraces of Phaseolus vulgaris L. Agriculture 9:1-16. https://doi.org/10.3390/agriculture9070149

3. Bertoldo JG, Coimbra JLM, Guidolin AF, de Andrade LRB, Nodari RO (2014) Agronomic potential of genebank landrace elite accesssions for common bean genetic breeding. Scientia Agric 71:120-125. https://doi.org/10.1590/S0103-90162014000200005

4. Boros L, Wawer A, Borucka K (2014) Morphological, phenological and agronomical characterisation of variability among common bean (Phaseolus vulgaris L.) local populations from the National Centre for Plant Genetic Resources: Polish Genebank. J Hort Res 22:123-130.

https://doi.org/10.2478/johr-2014-0029

Page 5/12 
5. Brasil-Ministério da Agricultura, Pecuária e Abastecimento (2006) Requisitos mínimos para determinação do valor de cultivo e uso de feijão (Phaseolus vulgaris), para a inscrição no registro nacional de cultivares - RNC. https://www.agricultura.gov.br. Accessed 11 Oct 2021

6. Cabral PDS, Soares TCB, Lima AB de P, Alves D de S, Nunes JA (2011) Diversidade genética de acessos de feijão comum por caracteres agronômicos. Rev Cienc Agron 42:898-905. https://doi.org/10.1590/S1806-66902011000400011

7. Carbonell SAM, Chiorato AF, Gonçalves JGR, Perina EF, Carvalho CRL (2010) Tamanho de grão comercial em cultivares de feijoeiro. Cienc Rural 40:2067-2073. https://doi.org/10.1590/S0103-84782010005000159

8. Carbonell SAM, Guerreiro Filho O, Siqueira WJ (2012) Contributions of the Instituto Agronômico (IAC) for plant breeding. Crop Breed Appl Biotechnol 12: 15-24. https://doi.org/10.1590/S1984-70332012000500003

9. Cargnelutti Filho A, Ribeiro ND, Jost E (2009) Número necessário de experimentos para a análise de agrupamento de cultivares de feijão. Cienc Rural 39:371-379. https://doi.org/10.1590/S0103-84782008005000059

10. Ceolin ACG, Gonçalves-Vidigal MC, Vidigal Filho PS, Kvitschal MV, Gonela A, Scapim CA (2007) Genetic divergence of the common bean (Phaseolus vulgaris L.) group Carioca using morpho-agronomic traits by multivariate analysis. Hereditas 144:1-9. https://doi.org/10.1111/j.2006.00180661.01943.x

11. Coelho CMM, Zilio M, Souza CA, Guidolin AF, Miquelluti DJ (2010) Características morfo-agronômicas de cultivares crioulas de feijão comum em dois anos de cultivo. Semina: Cienc Agrar 31:1177-1186. https://doi.org/10.5433/1679-0359.2010v31n4Sup1p1177

12. Correa AM, Gonçalves MC (2012) Divergência genética em genótipos de feijão comum cultivados em Mato Grosso do Sul. Rev Ceres 59:206212. https://doi.org/10.1590/S0034-737X2012000200009

13. Cruz CD (2016) Genes Software - extended and integrated with the R, Matlab and Selegen. Acta Sci Agron 38:547-552. https://doi.org/10.4025/actasciagron.v38i4.32629

14. Cruz CD, Carneiro PCS (2006) Modelos biométricos aplicados ao melhoramento genético. Editora UFV, Viçosa

15. Ctsbf Comissão Técnica Sul Brasileira de Feijão (2012) Informações técnicas para o cultivo de feijão na Região Sul brasileira 2012. Epagri, Florianópolis

16. de Lima MS, Carneiro JE de S, Carneiro PCS, Pereira CS, Vieira RF, Cecon PR (2012) Characterization of genetic variability among common bean genotypes by morphological descriptors. Crop Breed Appl Biotechnol 12:76-84. https://doi.org/10.1590/S1984-70332012000100010

17. Delfini J, Moda-Cirino V, Ruas C de F, dos Santos Neto J, Ruas PM, Buratto JS, Ruas, EA, Gonçalves LSA (2017) Distinctness of Brazilian common bean cultivars with carioca and black grain by means of morphoagronomic and molecular descriptors. Plos One 30:1-22.

http://doi.org/10.1371/journal.pone.0188798

18. dos Santos PRJ, Barelli MAA, Felipin-Azevedo R, da Silva VP, Gilio TAS, de Oliveira TC, Gonçalves DL, Poletine JP (2019) Genetic divergence among landraces and improved common bean genotypes in the central-southern region of Mato Grosso state in Brazil. Genet Mol Res 18:1-14. http://doi.org/10.4238/gmr18299

19. Gonçalves D de L, Ambrozio VC, Barelli MAA, Neves LG, Paiva Sobrinho S, da Luz PB, da Silva CR (2014) Divergência genética de acessos tradicionais de feijoeiros através de características da semente. Biosci J 30:1671-1681

20. Gonçalves D de L, Barelli MAA, dos Santos PRJ, de Oliveira TC, da Silva CR, Neves LG, Polentine JP, da Luz PB (2016) Variabilidade genética de germoplasma tradicional de feijoeiro comum na região de Cáceres-MT. Cienc Rural 46:100-107. http://doi.org/10.1590/0103-8478cr20140812

21. Guidoti DT, Gonela A, Vidigal MCG, Conrado TV, Romani I (2018) Interrelationship between morphological, agronomic and molecular characteristics in the analysis of common bean genetic diversity. Acta Sci Agron 40:1-9. https://doi.org/10.4025/actasciagron.v40i1.33032

22. Maziero SM, Ribeiro ND, Storck L (2015) Simultaneous selection in beans for architecture, grain yield and minerals concentration. Euphytica 205:369380. https://doi.org/10.1007/s10681-015-1392-5

23. Montgomery DC, Peck EA, Vining GG (2012) Introduction to linear regression analysis. Wiley, New York

24. Moura MM, Carneiro PCS, Carneiro JE de S, Cruz CD (2013) Potencial de caracteres na avaliação da arquitetura de plantas de feijão. Pesqui Agropec Bras 48:417-425. https://doi.org/10.1590/S0100-204X2013000400010

25. Nadeem MA, Karaköy T, Yeken MZ, Habyarimana E, Hatipoğlu R, Çiftçi V, Nawaz MA, Sönmez F, Shahid MQ, Yang SH, Chung G, Baloch FS (2020) Phenotypic characterization of 183 Turkish common bean acessions for agronomic, trading, and consumer-preferred plant characteristics for breeding purposes. Agronomy 10:1-20. http://doi.org/10.3390/agronomy10020272

26. Pereira HS, Mota APS, Rodrigues LA, de Souza TLPO, Melo LC (2019) Genetic diversity among common bean cultivars based on agronomic traits and molecular markers and application to recommendation of parent lines. Euphytica 215:1-16. http://doi.org/10.1007/s10681-018-2324-y

27. Ribeiro ND, Kläsener GR, Mezzomo HC, Possobom MTDF, Steckling S de M, Casagrande CR (2018) Combined selection in beans for cycle, plant architecture and grain yield. Biosci J 34:108-119. http://doi.org/10.14393/BJ-v34n6a2018-39853

28. Soltani A, Bello M, Mndolwa E, Schroder S, Moghaddam SM, Osorno JM, Miklas PN, McClean PE (2016) Targeted analysis of dry bean growth habit: interrelationship among architectural, phenological, and yield components. Crop Sci 56:3005-3015. http://doi.org/10.2135/cropsci2016.02.0119

29. Veloso JS, Silva W, Pinheiro LR, dos Santos JB, Fonseca Júnior NS, Euzebio MP (2015) Genetic divergence of common bean cultivars. Genet Mol Res 14:11281-11291. http://doi.org/10.4238/2015.September.22.22

\section{Tables}


Table 1 Results of the $F$ test of analysis of variance for the traits of lodging (LDG), general adaptation score (GAS), insertion of the first pod (IFP, cm), insertion of the last pod (ILP, cm), plant height $(\mathrm{PH}, \mathrm{cm})$, first-internode length $\left(1^{\mathrm{st}} \mathrm{IL}, \mathrm{cm}\right)$, second-internode length $\left(2^{\text {nd }} \mathrm{IL}, \mathrm{cm}\right)$, third-internode length $\left(3^{\text {rd }} / \mathrm{L}\right.$, $\mathrm{cm})$, fourth-internode length $\left(4^{\text {th }} \mathrm{IL}, \mathrm{cm}\right)$, fifth-internode length $\left(5^{\text {th }} \mathrm{IL}, \mathrm{cm}\right)$, hypocotyl diameter $(\mathrm{HD}, \mathrm{mm})$, epicotyl diameter (ED, mm), number of pods per plant (NPP), number of grains per plant (NGP), number of grains per pod (NGPOD), mass of 100 grains (M100G, g), and grain yield (YIELD, kg ha-1) obtained of 17 common bean genotypes evaluated in the 2016 rainy (I), 2017 dry (II), 2017 rainy (III) and 2018 dry (IV) seasons and in the combined experiments I and II; I, II and III; and I, II, III and IV 


\begin{tabular}{|c|c|c|c|c|c|c|c|c|c|c|c|c|c|c|c|c|c|c|}
\hline Experiment & LDG & & GAS & & IFP & & ILP & & $\mathrm{PH}$ & & $1^{\text {st }} \mathrm{IL}$ & & $2^{\text {nd } I L}$ & & $3^{\text {rd } I L}$ & & $4^{\text {th }}$ IL & \\
\hline & Geno & (G) & & & & & & & & & & & & & & & & \\
\hline I & 1.59 & ns & 1.38 & ns & 7.55 & * & 1.54 & ns & 1.85 & $\mathrm{~ns}$ & 1.05 & ns & 1.43 & ns & 1.52 & ns & 1.62 & ns \\
\hline II & 2.86 & * & 2.54 & * & 2.15 & * & 3.05 & * & 5.57 & * & 0.52 & ns & 1.65 & ns & 2.47 & * & 2.61 & * \\
\hline III & 1.94 & ns & 0.78 & ns & 3.46 & * & 3.50 & * & 6.16 & * & 1.82 & ns & 2.05 & * & 1.50 & ns & 1.50 & ns \\
\hline IV & 3.43 & * & 3.41 & * & 3.07 & * & 6.12 & * & 13.66 & * & 2.14 & * & 2.38 & * & 2.00 & * & 3.74 & * \\
\hline I and || & 0.76 & ns & 0.73 & ns & 0.93 & ns & 1.72 & ns & 2.54 & * & 1.87 & ns & 2.32 & ns & 2.17 & ns & 2.18 & ns \\
\hline I, II and III & 0.53 & ns & 1.39 & ns & 2.33 & * & 4.42 & * & 3.83 & * & 0.79 & ns & 2.84 & * & 2.76 & * & 1.62 & ns \\
\hline $\begin{array}{l}\text { I, II, III and } \\
\text { IV }\end{array}$ & 1.35 & ns & 1.68 & ns & 2.16 & * & 7.37 & * & 5.78 & * & 0.79 & ns & 2.03 & * & 1.76 & ns & 1.87 & ns \\
\hline
\end{tabular}

\section{Experiment (E)}

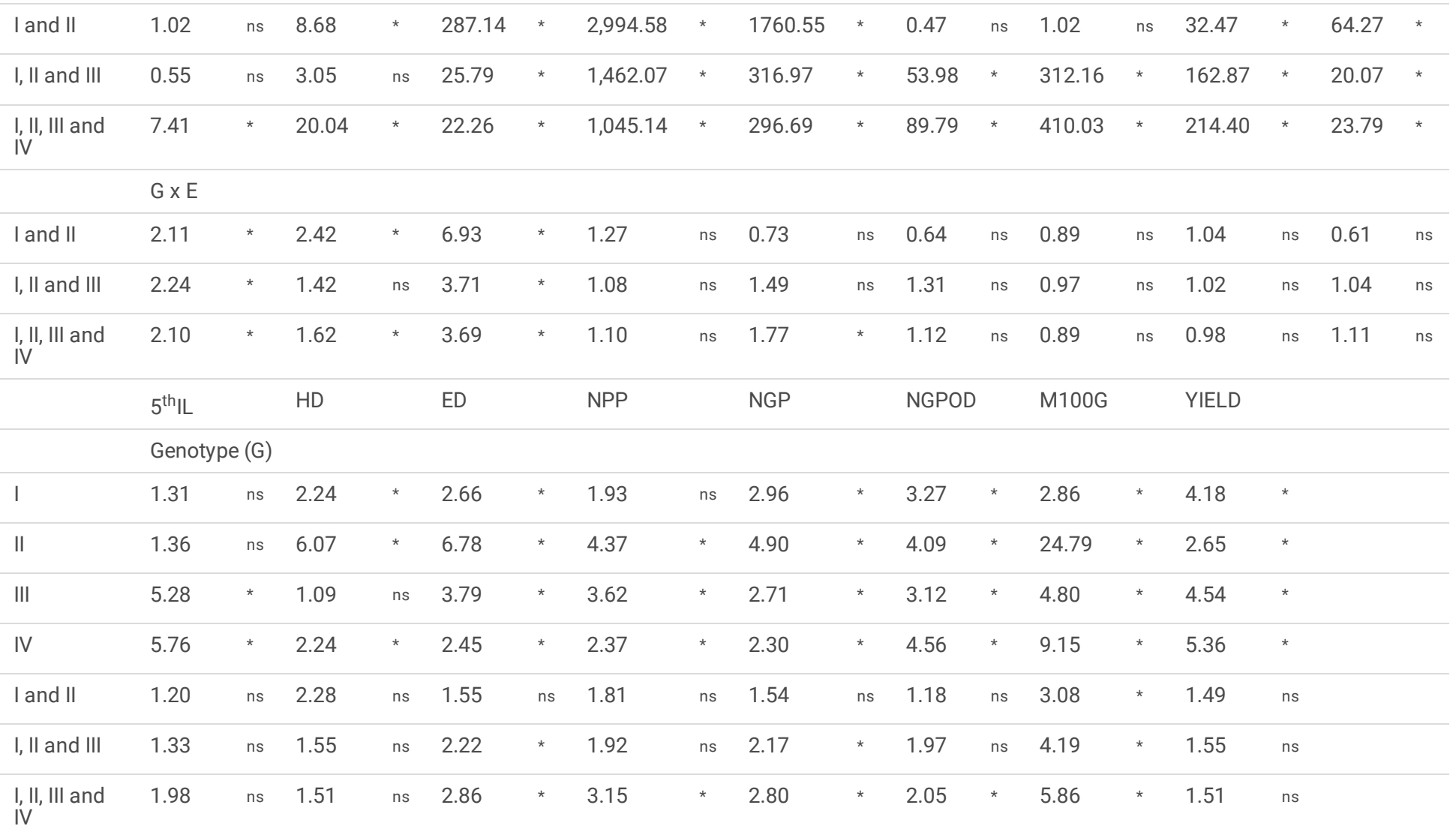

\section{Experiment (E)}

\begin{tabular}{lllllllllllllllllll}
\hline I and II & 194.29 & $*$ & 178.07 & $*$ & 327.40 & $*$ & 31.49 & $*$ & 32.78 & $*$ & 5.23 & $\mathrm{~ns}$ & 0.15 & $\mathrm{~ns}$ & 96.08 & $*$ \\
\hline I, II and III & 48.18 & $*$ & 131.18 & $*$ & 157.83 & $*$ & 60.24 & $*$ & 45.91 & $*$ & 3.98 & $\mathrm{~ns}$ & 2.91 & $\mathrm{~ns}$ & 52.95 & $*$ \\
\hline I, II, III and & 44.11 & $*$ & 102.60 & $*$ & 119.98 & $*$ & 45.94 & $*$ & 38.28 & $*$ & 3.77 & $\mathrm{~ns}$ & 52.63 & $*$ & 49.43 & $*$
\end{tabular}

\section{$G \times E$}

\begin{tabular}{llllllllllllllllll} 
I and II & 0.71 & ns & 1.98 & $*$ & 2.86 & $*$ & 1.65 & ns & 2.55 & $*$ & 3.24 & $*$ & 3.58 & $*$ & 3.15 & $*$ \\
\hline I, II and III & 1.17 & ns & 1.00 & ns & 2.63 & $*$ & 2.13 & $*$ & 2.21 & $*$ & 2.61 & $*$ & 3.23 & $*$ & 3.50 & $*$ \\
I, II, III and & 1.40 & ns & 1.05 & ns & 2.40 & $*$ & 1.75 & $*$ & 2.03 & $*$ & 2.82 & $*$ & 3.16 & $*$ & 3.79 & $*$
\end{tabular}

${ }^{*}$ Significant by $\mathrm{F}$ test at 0.05 probability. ${ }^{\mathrm{ns}}$ Non-significant. 
Table 2 Relative contribution (S.j) of the traits of lodging (LDG), general adaptation score (GAS), insertion of the first pod (IFP), insertion of the last pod (ILP), second-internode length ( $\left.2^{\text {nd } I L}\right)$, hypocotyl diameter (HD), number of pods per plant (NPP), number of grains per pod (NGPOD), mass of 100 grains (M100G), and grain yield (YIELD), obtained from Mahalanobis'generalized distance, of 17 common bean genotypes evaluated in the 2016 rainy (I), 2017 dry (II), 2017 rainy (III) and 2018 dry (IV) seasons and in the combined experiments I and II; I, II and III; and I, II, III and IV

\begin{tabular}{|c|c|c|c|c|c|c|c|c|}
\hline \multirow[t]{2}{*}{ Trait } & \multicolumn{2}{|c|}{ Experiment I } & \multicolumn{2}{|c|}{ Experiment II } & \multicolumn{2}{|c|}{ Experiment III } & \multicolumn{2}{|c|}{ Experiment IV } \\
\hline & S.j & Value,\% & S.j & Value, $\%$ & S.j & Value, $\%$ & S.j & Value, $\%$ \\
\hline LDG & 103.20 & 3.02 & 143.25 & 1.82 & 272.35 & 7.76 & 979.72 & 16.75 \\
\hline GAS & 151.22 & 4.42 & -197.49 & -2.51 & 66.54 & 1.90 & -2.74 & -0.05 \\
\hline IFP & 760.93 & 22.26 & 320.94 & 4.08 & 166.74 & 4.75 & 383.43 & 6.56 \\
\hline ILP & 302.13 & 8.84 & 352.05 & 4.48 & 570.97 & 16.26 & 958.84 & 16.39 \\
\hline $2^{\text {nd } I L}$ & 157.89 & 4.62 & 510.20 & 6.49 & 360.15 & 10.26 & 253.34 & 4.33 \\
\hline HD & 244.34 & 7.15 & 923.01 & 11.74 & 93.89 & 2.67 & 216.37 & 3.70 \\
\hline NPP & 318.62 & 9.32 & $1,150.35$ & 14.64 & 731.96 & 20.85 & 325.12 & 5.56 \\
\hline NGPOD & 456.63 & 13.36 & 319.98 & 4.07 & 294.38 & 8.38 & 544.18 & 9.30 \\
\hline M100G & 384.60 & 11.25 & $3,973.94$ & 50.56 & 486.98 & 13.87 & $1,472.33$ & 25.17 \\
\hline YIELD & 538.65 & 15.76 & 362.71 & 4.61 & 466.53 & 13.29 & 717.82 & 12.27 \\
\hline \multirow[t]{2}{*}{ Trait } & \multicolumn{2}{|c|}{ Experiments I and II } & & \multicolumn{2}{|c|}{ Experiments I, II and III } & & \multicolumn{2}{|c|}{ Experiments I, II, III and IV } \\
\hline & S.j & Value,\% & & S.j & Value,\% & & S.j & Value,\% \\
\hline LDG & 93.74 & 3.97 & & 35.11 & 2.02 & & 74.34 & 4.45 \\
\hline GAS & 63.48 & 2.69 & & 48.97 & 2.82 & & 43.06 & 2.58 \\
\hline IFP & 303.19 & 12.83 & & 236.40 & 13.62 & & 156.96 & 9.39 \\
\hline ILP & 172.90 & 7.32 & & 189.68 & 10.93 & & 228.71 & 13.69 \\
\hline $2^{\text {nd } I L}$ & 118.89 & 5.03 & & 113.65 & 6.55 & & 107.52 & 6.43 \\
\hline HD & 189.17 & 8.00 & & 61.05 & 3.52 & & 55.66 & 3.33 \\
\hline NPP & 136.06 & 5.76 & & 142.49 & 8.21 & & 140.07 & 8.38 \\
\hline NGPOD & 262.09 & 11.09 & & 193.46 & 11.15 & & 170.87 & 10.23 \\
\hline M100G & 693.77 & 29.36 & & 510.84 & 29.44 & & 526.52 & 31.51 \\
\hline YIELD & 329.73 & 13.95 & & 203.72 & 11.74 & & 167.01 & 10.00 \\
\hline
\end{tabular}

Table 3 Common bean genotypes classified in each group obtained by Tocher's optimization method, from Mahalanobis' generalized distance, in the experiments of 2016 rainy (I), 2017 dry (II), 2017 rainy (III) and 2018 dry (IV) seasons and in the combined experiments I and II; I, II and III; and I, II, III and IV 


\begin{tabular}{|c|c|c|c|c|c|c|c|}
\hline \multirow[t]{2}{*}{ Group } & \multicolumn{7}{|c|}{ Cluster of genotypes based in number of experiments } \\
\hline & I & II & III & IV & I and II & I, II and III & I, II, III and IV \\
\hline \multirow[t]{16}{*}{1} & BRS MG Uai & BRS MG Uai & SM 0312 & LEC 02-16 & BRS MG Uai & SM 0312 & LEC 02-16 \\
\hline & TB 03-11 & SM 0312 & GEN 45-2F-293P & BRS Valente & TB 03-11 & LP $11-117$ & BRS MG Uai \\
\hline & LP 09-33 & LEC 01-16 & LP 09-33 & CHP 01-182-48 & BRS Valente & GEN 45-2F-293P & LEC 01-16 \\
\hline & CHP 04-239-52 & CHP 04-239-52 & CHP 04-239-52 & TB 03-11 & CHP 04-239-52 & CHP 04-239-52 & LP 09-33 \\
\hline & GEN 45-2F-293P & Guapo Brilhante & ТВ 03-11 & GEN 45-2F-293P & GEN 45-2F-293P & ТВ 03-11 & CHP 04-239-52 \\
\hline & LP 11-117 & BRS Valente & BRS Valente & Carioca & LP 09-33 & IAC Netuno & GEN 45-2F-293P \\
\hline & CNFC 15097 & TB 03-11 & LEC 02-16 & LP 09-33 & IAC Netuno & Carioca & Carioca \\
\hline & IAC Netuno & LP 09-33 & LP 11-117 & LEC 01-16 & LEC 02-16 & BRS Valente & IAC Netuno \\
\hline & & CNFC 15097 & Guapo Brilhante & SM 0312 & LEC 01-16 & LP 09-33 & TB 03-11 \\
\hline & & Pérola & LEC 01-16 & CHP 04-239-52 & Carioca & BRS MG Uai & BRS Valente \\
\hline & & GEN 45-2F-293P & CHP 01-182-48 & LP 11-117 & CHP 01-182-48 & LEC 02-16 & LP 11-117 \\
\hline & & IAC Netuno & BRS MG Uai & & CNFC 15097 & CNFC 15097 & SM 0312 \\
\hline & & Carioca & IAC Netuno & & LP 11-117 & LEC 01-16 & CHP 01-182-48 \\
\hline & & CHP 01-182-48 & CNFC 15097 & & Guapo Brilhante & Guapo Brilhante & CNFC 15097 \\
\hline & & LEC 02-16 & Carioca & & SM 0312 & CHP 01-182-48 & Guapo Brilhante \\
\hline & & LP 11-117 & & & Pérola & & \\
\hline \multirow[t]{2}{*}{2} & LEC 02-16 & TВ 02-19 & ТВ 02-19 & BRS MG Uai & TB 02-19 & Pérola & Pérola \\
\hline & LEC 01-16 & & & Guapo Brilhante & & & \\
\hline \multirow[t]{3}{*}{3} & BRS Valente & & Pérola & TB 02-19 & & TB 02-19 & TB 02-19 \\
\hline & CHP 01-182-48 & & & CNFC 15097 & & & \\
\hline & & & & Pérola & & & \\
\hline 4 & Carioca & & & IAC Netuno & & & \\
\hline 5 & Pérola & & & & & & \\
\hline 6 & Guapo Brilhante & & & & & & \\
\hline 7 & TВ 02-19 & & & & & & \\
\hline 8 & SM 0312 & & & & & & \\
\hline
\end{tabular}

Table 4 Means of the traits of lodging (LDG), general adaptation score (GAS), insertion of the first pod (IFP, cm), insertion of the last pod (ILP, cm), secondinternode length $\left(2^{\mathrm{nd}} \mathrm{IL}, \mathrm{cm}\right)$, hypocotyl diameter (HD, mm), number of pods per plant (NPP), number of grains per pod (NGPOD), mass of 100 grains (M100G, g), and grain yield (YIELD, kg ha ${ }^{-1}$ ) obtained in each of the three groups established by Tocher's optimization method, from Mahalanobis' generalized distance, in the combined experiment I, II, III and IV (2016 rainy, 2017 dry, 2017 rainy and 2018 dry season crops)

\begin{tabular}{lllllllllll} 
Group & LDG & GAS & IFP & ILP & $2^{\text {nd } I L}$ & HD & NPP & NGPOD & M100G & YIELD \\
\hline Group 1 & 5.38 & 5.66 & 15.89 & 43.09 & 4.53 & 5.73 & 11.18 & 3.79 & 26.14 & $1,395.85$ \\
\hline Group 2 & 5.93 & 7.04 & 15.41 & 32.74 & 4.88 & 4.93 & 7.31 & 3.20 & 33.39 & 878.97 \\
\hline Group 3 & 5.83 & 6.95 & 15.84 & 34.46 & 4.73 & 5.10 & 7.78 & 3.25 & 32.81 & 935.40
\end{tabular}

\section{Figures}



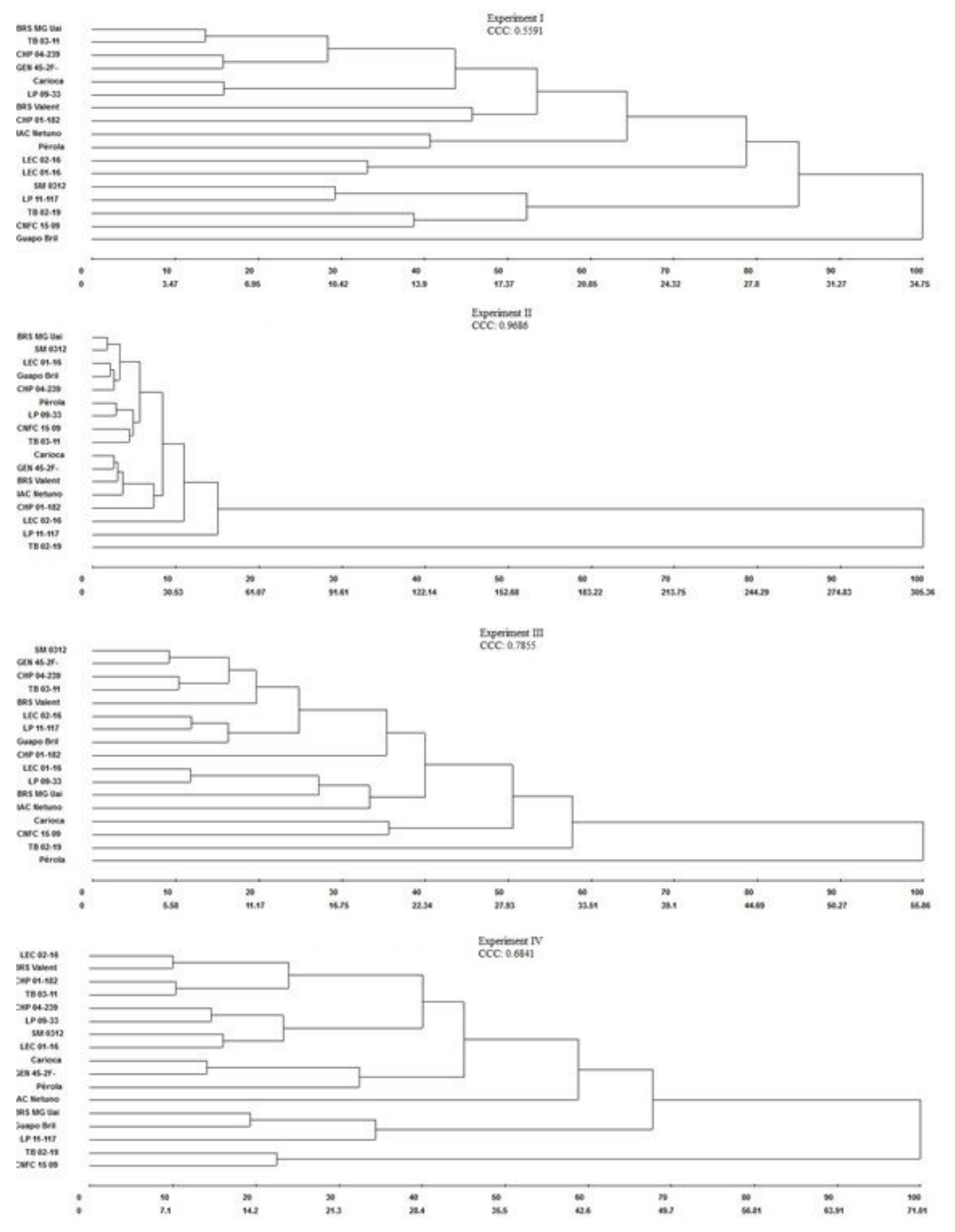

\section{Figure 1}

Dendrograms and cophenetic correlation coefficient (CCC) of the unweighted pair group method with arithmetic mean (UPGMA), from Mahalanobis' generalized distance, obtained in 17 common bean genotypes evaluated in the 2016 rainy (I), 2017 dry (II), 2017 rainy (III) and 2018 dry (IV) season crops. 

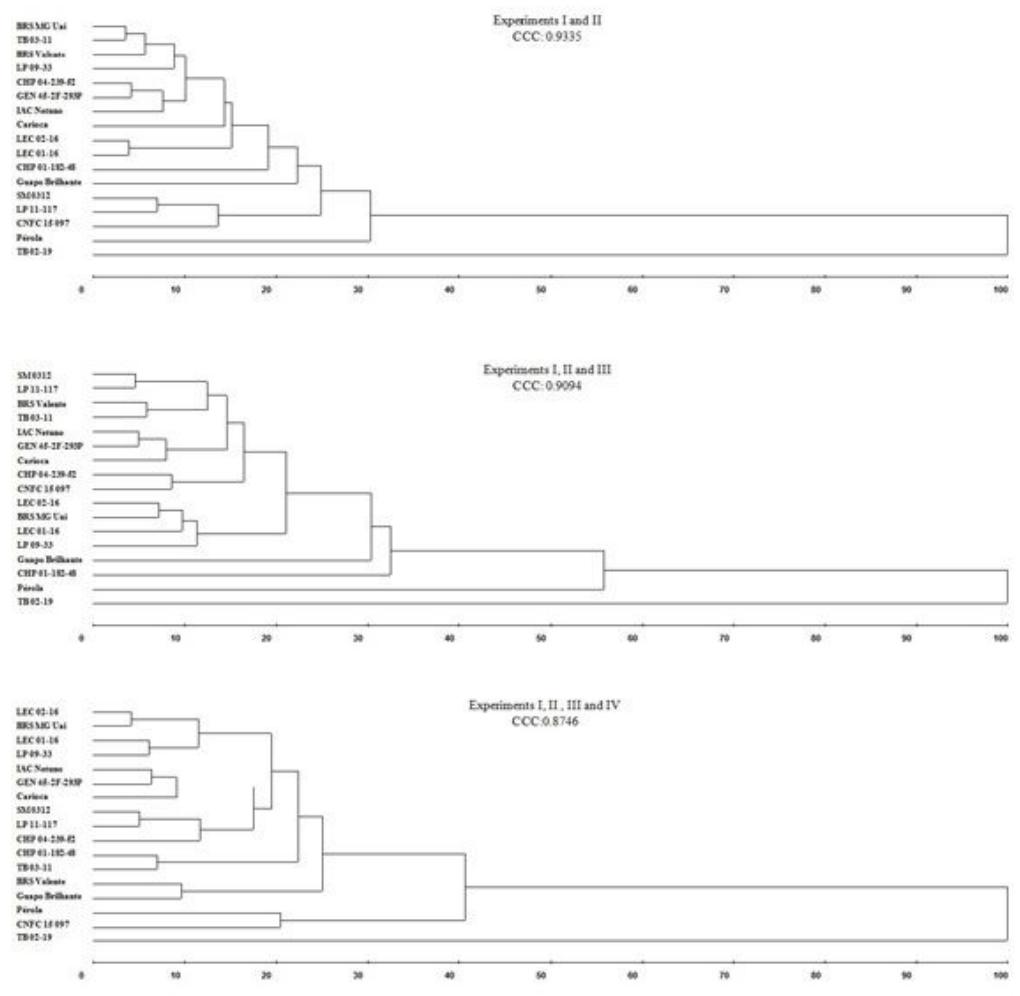

Figure 2

Dendrograms and cophenetic correlation coefficient (CCC) of the unweighted pair group method with arithmetic mean (UPGMA), from Mahalanobis' generalized distance, obtained in 17 common bean genotypes evaluated in the combined experiments I and II (2016 rainy and 2017 dry season crops), I, II and III (2016 rainy, 2017 dry and 2017 rainy season crops) and I, II, III and IV (2016 rainy, 2017 dry, 2017 rainy and 2018 dry season crops). 